\title{
22. FURTHER COMMENTS ON THE SOUTHWEST PACIFIC PALEOGENE REGIONAL UNCONFORMITIES
}

\author{
Anthony R. Edwards, New Zealand Geological Survey, Lower Hutt, New Zealand
}

\section{INTRODUCTION}

The regional Eocene-Oligocene and PaleoceneEocene unconformities discovered during Deep Sea Drilling Project Leg 21 were, together with two sequences across the Mesozoic-Cenozoic boundary, documented by Edwards (1973). However, at that time some aspects of these features were incompletely known. Consequently, during a subsequent visit to La Jolla, the opportunity was taken to reexamine some cores and to obtain several supplementary samples. The results of these investigations are given below together with additional possible correlatives of the regional unconformities. Although most of the consequent modifications are minor, the interpretation of the Eocene-Oligocene unconformity at Site 206 is significantly changed. The Eocene-Oligocene and Paleocene-Eocene regional unconformities are now known to be major features which, in terms of present geographic coordinates, occur over a $10^{\circ}$ to $20^{\circ}$ wide longitudinal belt extending from the equator to $48^{\circ}$ south and $44^{\circ}$ south, respectively.

\section{EOCENE-OLIGOCENE UNCONFORMITY}

\section{Site 206 (New Caledonia Basin)}

As a result of earlier investigations, it was concluded that this feature was recovered intact as an angular unconformity separating early late Eocene and early mid Oligocene sediments in Hole 206-15-2, 25-27 cm (613 m subbottom). However, reexamination of the core has convinced the writer that this identification is in error for two reasons. Firstly, it was discovered that the early late Eocene nannofossil sample taken at $38 \mathrm{~cm}$ in the working half of the core corresponds to a depth of $25 \mathrm{~cm}$ in the photographs of the archive half core. Secondly, it was observed that the sediment below $18 \mathrm{~cm}$ is highly bioturbated with occasional bedding planes $\left(20^{\circ}\right.$ dip at $36 \mathrm{~cm}$ ) whereas, as earlier reported, the overlying sediment is well bedded with a dip of about $30^{\circ}$. These results indicate that the feature previously identified as the regional unconformity probably represents only a very minor erosional break. Furthermore, since the nannofossil evidence is now known to indicate that the true position of the regional unconformity must occur between $6 \mathrm{~cm}$ and $25 \mathrm{~cm}$, it is concluded that it probably coincides with the marked sedimentological change occurring between two segments of core in Hole 206-15-2, $18 \mathrm{~cm}$. Although the unconformity was not recovered intact, there seems no reason to doubt the earlier conclusion that the apparent $10^{\circ}$ angularity of this feature is only of local extent.

\section{Other Southwest Pacific Occurrences}

Investigations on the subantarctic southwest Pacific materials obtained by DSDP Leg 29 indicate (Kennett,
Houtz, et al., 1975) that this unconformity almost certainly occurs at South Tasman Rise, Site 281, probably occurs at Tasman Basin, Site 283, and may have once occurred at the Campbell Plateau margin, Site 275. It does not appear to be present at Campbell Plateau, Site 277, nor in the South Australia Basin sequences at Sites 280 and 282. However, future investigations may indicate that these sequences are relatively condensed about the Eocene-Oligocene boundary. The other Leg 29 sites $(276,278,279$, and 284) did not reach this stratigraphic level.

Similar investigations on the tropical southwest Pacific sediments recovered by Leg 30 indicate (this volume) the presence of this unconformity at Coral Sea Basin, Site 287, and at Ontong-Java Plateau, Sites 288 and 289. It apparently does not occur at New Hebrides Basin Site 286. This stratigraphic level was not reached at South Fiji Basin, Site 285.

\section{Age}

The additional information given or referred to above does not appear to greatly modify the late late Eocene to earliest Oligocene age previously concluded for this feature. The most age-significant DSDP Leg 29 sequence obtained occurs at Site 281 where early late Eocene (Chiasmolithus oamaruensis Zone) sandy silts and silty clays are overlain by early early Oligocene (Blackites rectus Zone) glauconitic-quartz sand (Kennett, Houtz, et al., 1975).

\section{Possible Southwest Pacific Correlatives}

James and Evans (1971), Griffith and Hodgson (1971), and Stover and Evans (1973) outline the occurrence of a widespread subsurface mid Cenozoic unconformity in the offshore Gippsland Basin of southeast Australia. The unconformity usually separates a thick downwarped and somewhat eroded sequence of Late Cretaceous to (early?) late Eocene alluvial and deltaic sediments from the overlying Oligocene marine mudstones. But at a few localities near the center of the basin, the Oligocene is underlain by early to mid and (early?) late Eocene shallow marine sediments which fill channels cut in the older sediments. James and Evans (1971) interpret this situation as resulting from erosive marine transgression following downwarping. Elliot (1972) takes a different point of view. He argues that the Eocene pattern of sedimentation in the Gippsland Basin plus the absence of a correlative Eocene-Oligocene unconformity in the adjacent Bass and Otway basins indicates that the Gippsland Basin was rotated westward throughout the Eocene, particularly the late Eocene, and that this in turn suggests that most of the eastern margin of Australia was being uplifted during the late Eocene. He further supports these ideas by pointing out that the Gippsland Basin unconformity is correlative 
with both the regional Eocene-Oligocene unconformity of DSDP Leg 21 and with overthrusting and the emplacement of ultrabasic rocks in islands marginal to Australia.

The evidence marshaled by Elliot for a cause and effect relationship between major tectonic events and regional erosion, or at least nondeposition, in very diverse marine environments is most impressive. Unfortunately, the timing of the tectonic events appears to be much less accurately known than the age of the regional unconformity and this introduces an element of speculation into Elliott's case. Furthermore, his idea that the easternmost margin of Australia underwent uplift during the Eocene appears to be contrary to information now available which indicates that much of the present offshore easternmost Australia was subjected to marine transgression during the Paleogene (Oppel, 1970; Griffith and Hodgson, 1971; James and Evans, 1971; Palmieri, 1971; Burns, Andrews, et al., 1973; Heckel, 1973; Stover and Evans, 1973; and Kennett, Houtz, et al., 1975).

Another correlative of this feature may occur in the Anchor Cay No. 1 offshore exploration hole drilled by D/V Glomar Conception in $206 \mathrm{ft}(63 \mathrm{~m})$ of water at the northernmost end of the Great Barrier Reef. Oppel (1970) indicates that some 2135 meters of Cenozoic shallow shelf carbonates were encountered, but their biostratigraphy, apparently based on independent foraminiferal studies of drill cuttings, is contradictory. According to one unpublished report which Oppel quotes, the sequence is essentially complete from the upper mid Eocene upwards, whereas the other report concludes that Eocene to early Miocene and early Miocene to Pliocene unconformities occur at 1790 meters and 840 meters subbottom, respectively. Obviously further understanding of this sequence is dependent on the resolution of these conflicting statements. However, it is worthwhile pointing out that further southeast the Queensland Plateau sequence at DSDP Site 209 (Burns, Andrews, et al., 1973) contains late Eocene to late Oligocene and mid Miocene to mid Pliocene unconformities.

\section{PALEOCENE-EOCENE UNCONFORMITY}

\section{Site 208 (Northern Lord Howe Rise)}

Earlier investigations based on rather wide paleontological sampling suggested that this feature occurred, either as a disconformity or a paraconformity separating mid mid Paleocene and early mid Eocene sediments, in Hole 208-19-1, $102 \mathrm{~cm}$ (540 m subbottom). It was further speculated that the soft trace fossil burrows observed at $108 \mathrm{~cm}$ and $122 \mathrm{~cm}$ represented infilling younger sediment. Reexamination of the working half core revealed the previously unnoted presence of a chert disc between $100 \mathrm{~cm}$ and $102 \mathrm{~cm}$, but otherwise supported the position suggested earlier. Macroscopically, a change in the degree of induration is the most obvious lithologic event occurring at this position. Additional samples were taken at $95 \mathrm{~cm}$ and from within the burrow at $105 \mathrm{~cm}(=108 \mathrm{~cm}$ in the archive photograph). The upper sample yielded an abundant and diverse but poorly preserved early mid Eocene (mid Heretaungan) Discoaster elegans Zone nannoflora containing much nannofossil debris but no obvious reworking. The lower sample contains an abundant and moderately diverse but poorly preserved mid mid Paleocene (mid Teurian) Heliolithus kleinpelli Zone assemblage without obvious reworking or downhole contamination. Both of these results are consistent with the previously suggested biostratigraphy and confirm the earlier suggested position for the unconformity. However, the idea that the trace fossil burrows represent soft infilling younger sediment is no longer tenable (see above), and thus it follows that the Paleocene sediments may not have been semiconsolidated prior to the deposition of the Eocene sediments.

\section{Other Southwest Pacific Occurrences}

Investigations on the Subantarctic southwest Pacific materials obtained by DSDP Leg 29 indicate (Kennett, Houtz, et al., 1975) that this unconformity probably occurs at Tasman Basin, Site 283, may occur (as a highly condensed sequence) at Campbell Plateau, Site 277, and may once have occurred at the Campbell Plateau margin Site 275. The other Leg 29 sites $(276,278,279,280$ to 282 , and 284) did not reach this stratigraphic level.

Similar investigations on the tropical southwest Pacific sediments recovered by Leg 30 indicate (this volume) that this unconformity probably occurs at Ontong-Java Plateau Site 289 and may have once occurred at Ontong-Java Plateau Site 288. The other Leg 30 sites ( 285 to 287 ) did not reach this stratigraphic level.

\section{Age}

As far as the writer is aware, the additional information given or referred to above does not modify the latest Paleocene to early early Eocene age previously assessed for this feature.

\section{MESOZOIC-CENOZOIC BOUNDARY}

\section{Site 207 (Southern Lord Howe Rise)}

Previous investigations indicated that this feature occurs within the interval between Cores 207A-28, CC to $207 \mathrm{~A}-29-2,25 \mathrm{~cm}$ ( 301 to $310.5 \mathrm{~m}$ subbottom) interval. It was suggested that it probably occurred at one of two positions: (1) within the 8-meter unrecovered interval between Cores 28 and 29 , or (2) at 207A-29-1, $20 \mathrm{~cm}$ (309 m subbottom) where a lithologic change occurs. At the time of writing the existence of a Haumurian (latest Cretaceous) agglutinated benthonic foraminiferal assemblage at 207A-29-1, 20 to $21 \mathrm{~cm}$ (i.e., in the immediate vicinity of the lithologic change) was not known. The sediments below this lithologic change consist of thick and monotonous vaguely mottled oliveblack noncalcareous silty claystones which, during storage, have precipitated numerous small gypsum crystals. Two additional samples have been obtained from the top of Core 29. The lower sample, 207A-29-1, $16 \mathrm{~cm}$, consists of a medium gray concoidally fracturing chert containing a small cluster of unidentifiable calcareous benthonic foraminifera, most of which have been either broken or dissolved. Also present, scattered 
through the chert, are very small calcareous forms which appear to be planktonics. No age could be determined for either assemblage (N.de B. Hornibrook, personal communication, 1974). However, an earliest Cenozoic age seems feasible as minute planktonic foraminifera are characteristic of the early Danian. The upper sample, 207 A-29-1, $12 \mathrm{~cm}$, consists of a moderately soft dark gray noncalcareous mudstone which has been extensively bioturbated; the burrows usually are light gray, slightly calcareous and silty, but one medium sand grade example was noted. The mudstone matrix lacks obvious calcareous nannofossils, but one of the silty burrows yielded two specimens of Coccolithus cavus, four of Ericsonia subpertusa?, two of Prinsius martinii?, and four unidentified Cenozoic forms. This extremely sparse and very poorly preserved nannoflora is of definite Cenozoic age and might be of Danian (i.e., basal Cenozoic) age.

The above lithologic and paleontologic information can be construed as indicating that the mudstone represents sediment deposited immediately prior to a hiatus which was accompanied by intense bioturbation. However, it should be pointed out that the burrows in the mudstone are relatively porous and thus the possibility that they have been preferentially infiltrated by drilling mud containing very low numbers of nannofossils cannot be excluded. Furthermore, since most of Core 207-28 appears to have fallen back into the hole during core retrieval operations, both the mudstone and the chert could easily have come from anywhere within the essentially unrecovered interval between 301 and 309 meters subbottom. Accordingly, it is concluded that at Site 207A the Mesozoic-Cenozoic boundary occurs somewhere within the interval between Cores 207A-28, $\mathrm{CC}$ to 207A-29-1, $20 \mathrm{~cm}$ and may coincide with a hiatus.

\section{Site 208 (Northern Lord Howe Rise)}

Earlier investigations indicated that this feature is a paraconformity occurring at $208-33-1,57 \mathrm{~cm}$ and coincides with a 2-mm-thick interval of rounded white granules which might be reworked chalk. However, additional sampling indicates that these granules are, like the adjacent sediments, composed of slightly calcareous silicitite. Accordingly, the other obvious explanation for the origin of these granules, that they are small fecal pellets, is invoked. This sample $(208-33-1,57 \mathrm{~cm})$ contains a very rare and more or less poorly preserved calcareous nannoflora dominated by indeterminate fragments and the dissolution-resistant Late Cretaceous taxon Micula staurophora. Other taxa present, mainly represented by single specimens, are the Late Cretaceous forms Arkhangelskiella cymbiformis, Chiastozygus amphipons, Deflandrius spinosus, Eiffellithus eximus, and Kamptnerius magnificus; the Mesozoic-Cenozoic boundary species Markalius astroporus and Thoracosphaera operculata; and the entirely Cenozoic taxa Biantholithus sparsus (one fragment), Coccolithus ? cavus, Conococcolithus panis (four specimens), Prinsius martinii (one specimen; contamination?), Rhabdothorax sp. (one specimen; earliest known record), and Zygodiscus sigmoides? (one fragment). This assemblage, which is immediately underlain (at $58 \mathrm{~cm}$ ) and overlain (at 54 $\mathrm{cm}$ ) by late Maestrichtian (latest Mesozoic) and basal
Danian (earliest Cenozoic) nannofloras, respectively, is considered to be of basal Danian age (Conococcolithus panis Zone). The presence of Late Cretaceous taxa in this assemblage is attributed to reworking, a conclusion which suggests that the fecal pellets were produced by a benthonic invertebrate. This in turn suggests that stagnant environmental conditions did not prevail at Site 208 during the Mesozoic-Cenozoic boundary event.

Using high quality seismic profiles, Bentz (1974) was able to recognize both the Eocene-Oligocene and, less certainly, the Paleocene-Eocene regional unconformities over much of the southern Lord Howe Rise and northern Challenger Plateau. A block-faulting regime changed to the present "stable" tectonic situation in the mid Cenozoic.

By seismic means Pinchin and Hudspeth (1975) were able to recognize the Eocene-Oligocene unconformity of DSDP Site 209 as an angular unconformity over most of the Coral Sea (Queensland) Plateau and as a conformable feature in the adjacent northward deepening Queensland Trough. This situation is compatible with the hypothesis (Edwards, this volume) that along the eastern margin of Australia the regional unconformity results from erosion by an intense southward flowing near-surface current rather than by a northward moving bottom current.

\section{FINAL COMMENTS}

The following is a short list of the omissions from, and corrections to Edwards (1973).

1) Add the following footnote to Table 1 (p. 707): "In the writer's opinion this diagram tends to telescope the early Runangan and Late Whaingaroan intervals."

2) Add references (see below) to Hornibrook (1962, 1971).

3) Read page 701 , right-hand column line 2 as: “... unconformity, at $206 \mathrm{C}-15-2,25.5-27.5 \mathrm{~cm}, \ldots$.

4) Read page 703 , right-hand colume line 7 as "... the regional unconformity sensu possibility A."

5) Read page 711 , left-hand column line 18 as: “... at 208-29-2, 102 cm."

\section{ACKNOWLEDGMENTS}

The writer acknowledges with thanks the assistance given by Walt Friesen of the Deep Sea Drilling Project core laboratory, and by N.de B. Hornibrook and Neville Orr of the New Zealand Geological Survey, Lower Hutt, New Zealand.

\section{REFERENCES}

Bentz, F.P., 1974. Marine Geology of the southern Lord Howe Rise, southwest Pacific. In Burk, C.A. and Drake, C.L., (Ed.), The geology of continental margins: New York (Springer Verlag).

Burns, R.E., Andrews, J.E., et al., 1973. Initial Reports of the Deep Sea Drilling Project Volume 21: Washington (U.S. Government Printing Office).

Edwards, A.R., 1973. Southwest Pacific regional unconformities encountered during Leg 21 . In Burns, R.E., Andrews, J.E., et al., Initial Reports of the Deep Sea Drilling Project, Volume 21: Washington (U.S. Government Printing Office), p. 701-720.

Elliott, J.L., 1972. Continental drift and basin development in south eastern Australia: APEA J., v. 12, p. 46-51. 
Griffith, B.R. and Hodgson, E.A., 1971. Offshore Gippsland Basin fields: APEA J., v. 11, p. 85-89.

Heckel, H., 1973. Late Oligocene to Recent nannoplankton from the Capricorn Basin (Great Barrier Reef Area): Geol. Surv. Queensland Publication 359 (Paleont. Papers 33).

Hornibrook, N.de B., 1962. The Cretaceous-Tertiary Boundary in New Zealand: New Zealand Geol. Geophys. J., v. 5, p. 295-303.

1971. New Zealand climate: New Zealand Geol. Surv. Rept. 47.

James, E.A. and Evans, P.R., 1971. The stratigraphy of the offshore Gippsland Basin: APEA J., v. 11, p. 71-74.
Kennett, J.P., Houtz, R.E., et al., 1975. Initial Reports of the Deep Sea Drilling Project, Volume 29: Washington (U.S. Government Printing Office).

Oppel, T.W., 1970. Exploration of the southwest flank of the Papuan Basin: APEA J., v. 10, p. 62-69.

Palmieri, V., 1971. Tertiary subsurface biostratigraphy of the Capricorn Basin: Geol. Surv. Queensland Rept. 52.

Pinchin, J. and Hudspeth, J.W., 1975. The Queensland Trough: Its petroleum potential based on some recent geophysical results: APEA J., v. 15, p. 21-31.

Stover, L.E. and Evans, P.R., 1973. Upper Cretaceous-Eocene spore-pollen zonation, offshore Gippsland Basin, Australia: Spec. Publ. Geol. Soc. Australia 4, p. 55-72. 